\title{
Rituales judiciales: Aproximación a las funciones de los juramentos
}

\section{Judicial rituals: Approximation to the functions of oaths}

Rituais judiciais: Aproximação das funções dos juramentos

Des rituels judiciaires: Une approche aux fonctions des serments

司法仪式:宣誓功能的探讨

\author{
Jonatan L. Bregantic ${ }^{1}$ Universidad de Buenos Aires, \\ Argentina
}

Revista Derechos en Acción ISSN 2525-1678/ e-ISSN 2525-1686

Año 4/No 13, Primavera 2019 (21 septiembre a 20 diciembre), 202-248

DOI: https://doi.org/10.24215/25251678e337

ORCID: https://orcid.org/0000-0003-3743-0306

Recibido: 07/08/2019

Aprobado: 25/10/2019

Resumen: Etnológicamente, hablamos de paradigmas inquisitivos y acusatorios; siendo los primeros herederos del sistema romano canónico y, los segundos, de las ordalías carolingias. Si bien según el principio de inconmensurabilidad cada paradigma evoluciona en formas disímiles, el juramento ex officio actuó durante algún tiempo de denominador común, aunque, vale aclarar, el juramento ordálico fue patrimonio exclusivo del trial. Hablando sobre su funcionalidad; mientras el juramento ex officio tenía un sentido probatorio [confesión], por eso se relaciona con la tortura e incidía sobre el nemo tenetur, el juramento ordálico actúa como aceptación de la puesta a prueba judicial, tras la declaración performativa

1 Abogado (Universidad de Buenos Aires), cursando la Especialización en Derecho Penal, Procesal Penal y Criminología. Es autor de numerosos trabajos de la especialidad.

Email: bregantic_jl@live.com.ar. 
traducida en no culpabilidad, en la audiencia de arraigo. Posteriormente, el acusado puede testificar en su propia causa.

Palabras claves: Inquisición; juramento; confesión; tortura; enquête; jury trial.

Abstract: Ethnologically, we speak of inquisitive and accusatory paradigms; being the first heirs of the Roman canonical system and, the second, of the Carolingian ordeals. Although according to the principle of immeasurability each paradigm evolves in dissimilar forms, the ex officio oath acted for some time as a common denominator, although, it is worth clarifying, the ordained oath was the exclusive patrimony of trial. Talking about its functionality; while the ex officio oath had a probative sense [confession], that is why it is related to torture and affected the nemo tenetur, the ordalic oath acts as an acceptance of judicial proof, after the performative declaration translated into not guilt, in the arraigo hearing. Subsequently, the accused may testify in his own case.

Keywords: Inquisition; oath; confession; torture; enquête; jury trial.

Resumo: Etnologicamente, falamos de paradigmas inquisitivos e acusatórios; sendo os primeiros herdeiros do sistema romano canônico e, os segundos, das ordalías carolíngias. Sim bem de acordo com o princípio da incomensurabilidade cada paradigma evolua de maneiras diferentes, o juramento ex officio atuou por algum tempo de denominador comum, embora, valha a pena esclarecer, que o juramento ordálico foi patrimônio exclusivo do trial. Falando sobre sua funcionalidade; enquanto 0 juramento ex officio tinha um sentido probatório [confissão], é por isso se relaciona com à tortura e afetou sobre 0 nemo tenetur, 0 juramento ordálico atua como aceitação da posta à prova judicial, após a declaração performativa traduzida como não culpabilidade, na audiência de enraizamento. Posteriormente, 0 acusado pode testemunhar em seu próprio caso.

Palavras-chave: Inquisição; juramento; confissão; tortura; enquête; jury trial

Résumé: D'un point de vue ethnologique, on parle de paradigmes inquisiteurs et accusateurs. Les premiers sont héritiers du système canonique romain et les seconds, des ordalies carolingiennes. Bien que, selon le principe d'incommensurabilité, chaque paradigme évolue sous des formes 
différentes, le serment ex officio a été le dénominateur commun pendant longtemps, bien que -il convient de le préciser-, le serment ordinal était patrimoine exclusif du procès. En ce qui concerne ses fonctionnalités; alors que le serment ex officio avait une valeur probante [confession] -voilá pourquoi il est associé à la torture et a une incidence sur le Nemo Tenetur-, le serment ordinal sert d'acceptation de de l'épreuve judiciaire, après la déclaration performative traduite en non culpabilité à l'audience d'arraigo. Ultérieurement, l'accusé peut témoigner dans son propre cas.

Mot-clés: inquisition, serment, confession, torture, interrogatoire, jury, process

摘要: 从民族学的角度讲, 我们谈论的是好奇和指责的范式。是规范 的罗马体系的第一个继承人, 第二个是加洛林式的苦难。尽管按照 不可通约性原则, 每种范式都以不同的方式演变, 依职权宣誓起了 一段时间的共同点, 尽管值得澄清的是, 序言宣誓是审判的唯一遗 产。谈论其功能; 依职权宣誓具有一定的感性 [认罪], 这就是为什么 它与酷刑有关, 并影响了nemo tenetur, 但在将有表现力的声明翻 译为无罪之后, 按序宣誓即接受了司法测试。根深蒂固的观众。随 后, 被告可以在自己的案件中作证。

关键字: 宗教裁判所, 宣誓认罪折磨陪审团审判

\section{Introducción}

En las siguientes páginas abordaré -o, por lo menos, intentaré aproximarme- una ríspida labor: el estudio de las funciones de los juramentos en las misas judiciales. Lógicamente, la idea suena promisoria, aunque hay que proceder con la mayor cautela. Esta propuesta pretende trascender la clásica disquisición etnológica sobre los juramentos judiciales -ex officio, por un lado, ordálico, por otro- para abocarse concretamente, a través de perspectivas multidisciplinarias (v. gr., históricas, epistemológicas, antropológicas, etnológicas y jurídicas), a los funcionamientos litúrgicos.

Así, las interrogantes propuestas se inclinan hacia otros aspectos; ya no he de preguntar, ¿de dónde surgen? ¿Cuáles 
son? ¿O qué son? Sino directamente, "¿cómo funcionan?». En este punto, conviene hacerle al lector una advertencia, una propuesta y una promesa. Liminarmente, la advertencia consiste en que resulta imperativo manejar ciertos conocimientos históricos que, a fuerza de pragmatismo, serán refrescados en este trabajo. En este orden de ideas, la propuesta implicará la aplicación de las consideraciones arribadas a procedimientos comparados determinados, v. gr., provincia de Buenos Aires, propio de la enquête, e Inglaterra y Estados Unidos, propios del jury trial. La promesa, por último, consiste en trazar un puente, siguiendo la línea de mi libro Iura novit curia, poder y verdad, entre las disciplinas empleadas para que puedan ser concebidas desde una visión holística.

\section{El impacto de las ordalías carolingias}

Merece la pena tomarse el tiempo, aunque sea escasamente, para pasar página del impacto de las ordalías carolingias. Seguiré con la línea de análisis propuesta en el Capítulo III de Iura novit curia, poder y verdad ${ }^{2}$.

Iniciaré con una pregunta disparadora, ¿qué son las ordalías? Los profesores Germán Sucar y Jorge Cerdio Herrán ${ }^{3}$, en su increíble trabajo titulado Derecho y Verdad II. Genealogía(s) consideran que las ordalías son -en presente, porque todavía existen, v. gr., en tribus africanas- una modalidad de resolución de litigios consistente en una puesta a prueba, en general de tipo física, de una o de las dos partes en conflicto (unilateralidad o bilateralidad; v. gr., del agua o hierro candente, de la primera, y el duelo judicial, de la segunda) precedida por un juramento o declaración solemne de ambas, énfasis en este punto, cuyo éxito o fracaso determinará apelando a lo sobrenatural, su inocencia

2 Bregantic, Jonatan L., Iura novit curia, poder y verdad, Ed. Ad Hoc, Buenos Aires, 2019, p. 117 y ss.

3 Sucar, Germán y Cerdio Herrán, Jorge A. (eds.), Introducción en Derecho y Verdad II. Genealogía(s), Ed. Tirant lo Blanch, Valencia, 2015, p. 50. 
o culpabilidad, o en forma más general, a quien le asiste el derecho. Así, las ordalías pueden diferenciarse del juramento decisorio, la adivinación y la tortura. De la primera, grosso modo porque el juramento no exigía una puesta a prueba. De la segunda, porque la interpretación de un signo no está formalmente ligada a la palabra judicial, no pudiendo ser condenado o exonerado nadie. Por último, porque el sufrimiento no es inherente de los juicios de Dios, puesto que los hay indoloros. En cambio, la tortura no está destinada a confundirse con la decisión y apunta únicamente a obtener la confesión que justifica una decisión judicial ${ }^{4}$.

Ahora bien, ¿ordalía es sinónimo de juicios de Dios? En las liturgias antiguas los hombres empeñaban la solemnidad de la palabra ante las fuerzas divinas. Así, en Grecia se juraba "por Zeus, Apolo y la Tierra" mientras que en Escandinavia "por Freya, Njördr y el todo poderoso Odín". El excelso libro del catedrático medievalista de las Universidades de Liège y de Saint Louis de Bruselas, Robert Jacob ${ }^{5}$, titulado La gracia de los jueces. La institución judicial y lo sagrado en Occidente, nos señala que antes del siglo VIII no existía la construcción cultural de la ordalía como "juicio de Dios», iudicium Dei. Así, el ritual ordálico era desempeñado bajo creencias esencialmente politeístas hasta que las divinidades paganas fueron reemplazadas por el Dios único, provocándose la reconfiguración del ritual orientado al monoteísmo; el Dios verdadero adopta todas las características que carecían sus antecesores y que hacen de éste un

4 El genio francés de Michel Foucault en su trabajo Obrar mal, decir la verdad. La función de la confesión en la justicia, aclara que la confesión (forma de decir veraz) y la verdad se vinculaban pues, al confesar, manifestar la verdad, el mal era arrancado del cuerpo y del alma del confesante. Un alma se volvía más blanca si confesaba que era negra. Igualmente, los inquisidores sabían que para que las confesiones arrancadas bajo la tortura fueran confesiones, era necesario que se repitieran tras el suplicio (Foucault, Michel, Obrar mal, decir la verdad. La función de la confesión en la justicia, Ed. Siglo Veintiuno, Buenos Aires, 2014, pp. 23-25).

5 Jacob, Robert, La gracia de los jueces. La institución judicial y lo sagrado en Occidente, Ed. Tirant lo Blanch, Valencia, 2017, p. 141. 
juez perfecto: es omnisciente, omnipotente y puede discriminar perfectamente el bien del $\mathrm{mal}^{6}$, características que luego pasarán al jury trial. La evolución de las ordalías se intensifica en el período carolingio así el capitulario de Carlomagno emitido en Aquisgrán en el 809 resulta contundente: "Que todos crean en el juicio de Dios, sin ponerlo en duda" (Ut omnes judicium Dei credant, absque dubitatione $)^{7}$.

Una disputa crucial sobre las ordalías europeas, zanjada correctamente por el jurista Robert Jacob y aclarada por Germán Sucar y Jorge Cerdio Herrán ${ }^{8}$ es la problemática antropológica de la naturaleza de los juicios de Dios. El prestigioso profesor de Historia del Derecho en la Universidad de St. Andrews, John Hudson', al igual que muchísimos otros teóricos del Derecho, proclaman que por mucho tiempo coexistieron diversas formas de prueba, algunas basadas en el conocimiento humano, más terrenales, otras como los juicios de Dios se referían a lo sobrenatural; surgiendo de esta forma, la distinción entre las denominadas "pruebas racionales» y las "pruebas irracionales».

En cambio, Robert Jacob $^{10}$ explica que, concibiendo las ordalías como pruebas, se pretende proyectar sobre los procesos arcaicos las lógicas de los procesos modernos. Ellas presuponen que quienes practicaban los juicios de Dios o el juramento tienen la misma intención que los magistrados modernos de buscar la verdad, entendiendo epistemológicamente esta última como correspondencia, correspondencia entre la representación de los hechos aceptada por el juez y los que se produjeron (aquello que denominaré: alétheia clásica). La prueba, continúa

\footnotetext{
6 Ibídem..., p. 112.

7 Ibídem..., p. 170.

8 Sucar, Germán y Cerdio Herrán, Jorge, Introducción, en Derecho y Verdad II. Genealogías, ob. cit., pp. 53-56.
}

9 Hudson, John, Prueba y verdad en el temprano derecho inglés medieval, en Derecho y Verdad II. Genealogía(s)..., ob. cit., p. 500.

10 Jacob, Robert, La gracia de los jueces. La institución judicial y lo sagrado en Occidente, ob. cit., p. 53. 
el autor, es la técnica que permite alcanzar la adecuación de correspondencia precedente. Es una etapa preparatoria y distinta de la sentencia. Ahora bien, las ordalías no se inscriben en esta lógica; ellas no preparan sentencias, sino que constituyen una sentencia en sí misma. No pretenden descubrir la materialidad de hechos pasados y, si establecen una verdad, se trata de una verdad entendida en términos irreductibles de la verdad fáctica (que llamaré: alétheia arcaica).

Según, Germán Sucar y Jorge Cerdio Herrán las ordalías actualizan la sanción sobrenatural del juramento decisorio sometiendo al justiciable a una puesta a prueba [épreuve] que manifiesta, en el momento mismo en que se efectúa, la aprobación o la desaprobación de su tesis. Constituyen una sentencia per se. Por lo tanto, se trata de una puesta a prueba [épreuve] y no de una prueba [preuve ${ }^{11}$.

En 1215, habiéndose ya estipulado la Magna Carta inglesa, ocurre la supresión de las ordalías unilaterales a instancias del IV Concilio de Letrán ${ }^{12}$, convocado por el papa Inocencio III, prohibiendo la participación sacerdotal, cercenándose así su credibilidad e hiriéndolas de muerte. Robert Jacob ${ }^{13}$, ilustra que las ordalías carolingias no funcionaban sino gracias a la participación activa de los sacerdotes quienes oficiaban la misa del juicio (missa iudicci) ${ }^{14}$, distribuían la comunión a los sometidos

\footnotetext{
11 Sucar, Germán y Cerdio Herrán, Jorge, Introducción, en Derecho y Verdad II. Genealogías..., ob. cit., p. 56.

12 La prohibición canónica de las ordalías fue ocurriendo en forma paulatina. Así, el papa Nicolás I dispuso en una epístola que estos rituales eran contrarios a la ley divina por resultar contrarios al versículo «No tentarás al Señor tu Dios» (Nuevo Testamento, Mateo 4:7, Lucas 4:12).

13 Jacob, Robert, Los modos rituales de resolución de los conflictos y la construcción de la verdad judicial (Antropología y Alto Medioevo occidental), en Derecho y Verdad II. Genealogía(s), ob. cit., p. 553.

14 Así, pueden clasificarse cuatro oraciones: bendiciones, abjuraciones, conjuraciones y súplicas. Se bendicen los elementos. Se les adjura para que manifiesten la voluntad de Dios, pero también se adjura al justiciable para que se abstenga de pasar la puesta a prueba y se declare culpable si lo es. Se conjura al diablo y, por último, se suplica a Dios que
} 
a prueba [épreuve], impartía bendiciones, adjudicaciones e invocaciones de rigor sobre el agua, el hierro o los alimentos por medio de los cuales debía manifestar la verdad de la palabra del ejecutante. El juicio de Dios, puntualiza, de la puesta a prueba [épreuve] judicial participaba de la misma esencia del juicio al alma o el juicio final.

Los efectos de la prohibición de los juicios de Dios fueron brutales. En realidad, el impacto en la conformación de los paradigmas procesales hegemónicos no lo generaron las ordalías en sí mismas, sino su ausencia. Mientras que en Inglaterra el vacío dejado fue ocupado por el jury trial, que conserva importantes y destacados rasgos ordálicos ${ }^{15}$, en el continente es reemplazada por la enquête romano canónica. Esta transformación da lugar al surgimiento de los dos paradigmas procesales hegemónicos: el trial y la enquête. Paradigmas que tienen diferentes formas de investigar y comprobar la verdad de los hechos objeto de los procesos; dos imágenes distintas del ideal de justicia divina.

\section{El paradigma del procès: historia, procedimientos y juramentos}

La prohibición de los juicios de Dios por el IV Concilio Lateranense (1215-1216) provoca una definitiva ruptura cuyos vestigios perduran hasta nuestros días. Según Robert Jacob ${ }^{16}$, maestro e inspiración en la materia, al haberse abandonado las ordalías carolingias -esencialmente monoteístas- los eclesiásticos

juzgue (Jacob, Robert, La gracia de los jueces. La institución judicial y lo sagrado en Occidente, ob. cit., p. 177).

15 No se entablará una disputa sobre la obscura genealogía del juicio por jurados, sino más bien, sobre su funcionamiento como sustituto de los juicios de Dios. Cabe aclararse que los jurados pueden hallarse en la República Romana antigua (v. Harfuch, Andrés, El juicio por jurados en la provincia de Buenos Aires, Ed. Ad Hoc, Buenos Aires, 2013, p 138) y también en la Carta de las Libertades del año 1100, cuyo texto es tomado por la Magna Carta inglesa de 1215.

16 Jacob, Robert, Los modos rituales de resolución de los conflictos y la construcción de la verdad judicial (Antropología y Alto Medioevo occidental), en Derecho y Verdad II. Genealogía(s), ob. cit., pp. 557-558. 
debieron experimentar nuevas técnicas de resolución de litigios no pudiendo, sin contradecirse, seguir instrumentalizando la omnisciencia divina. Omnisciencia suprema que continuaría manifestándose en el incipiente paradigma del trial. Así nace el Dios enquêteur, o Dios investigador. Para los canonistas el Dios de verdad, entronizado como su Dios de referencia, fue aquél que castigó a las ciudades de Sodoma y Gomorra; cuando una queja se alzó contra las metrópolis, dice el Génesis, Dios no se limitó a responder: "Yo sé», afirmación más que lógica puesto que al ser omnisciente no podría ignorar lo que sucedía. Respondió: "Quiero descender y ver si han becho o no lo que indica el clamor que, contra ellos, ha venido hasta mí; lo sabré» (Génesis 18:21). La parábola bíblica, que enseña la primera enquête, importa una narrativización como estrategia de legitimación ideológica propuesta por los juristas de la Iglesia. Los canonistas eligieron un Dios que había repudiado excepcionalmente su omnisciencia. Un Dios que debía ser tomado de ejemplo por el Papa que, como juez humano, era el magistrado supremo de la Iglesia tras las reformas gregorianas.

El enaltecimiento del Dios investigador por el derecho romano canónico, propició la aparición de la enquête y, en materia penal, el procedimiento inquisitivo; este procedimiento, tenía por finalidad [verificar] establecer los hechos objeto del proceso, por medio de magistrados que instruían investigaciones de oficio, escritas y secretas, empleando la tortura para arrancar la confesión. En otras palabras, la creación de una verdad judicial.

En este punto, me apartaré de las consideraciones realizadas en el tercer capítulo de Iura novit curia, poder y verdad (\$3.1). Creo que resulta más propicio e interesante para este trabajo abocarme a los componentes litúrgicos.

Liminarmente, merece la pena refrescar la memoria con la inestimable colaboración del investigador español José Ignacio de la Torre ${ }^{17}$. En 1184, en el Concilio de Verona, bajo el papado

17 Ver De la Torre, José Ignacio, Breve historia de la Inquisición, Ed. Nowtilus, Madrid, 2014. 
de Lucio III, se crea la denominada "Inquisición episcopal", base fundacional de la que luego sería el Santo Oficio, por la decretal Ad Abolendam, o Magna Carta inquisitorial. La Inquisición episcopal tenía por finalidad perseguir sectas heréticas, entre las que podían destacarse por aquella época, los cátaros, patarinos, humuliati, pobres de Lyon y josefinos. Los inquisidores, que usualmente iniciaban las persecuciones de oficio, sólo rendían cuentas del desarrollo de sus actividades al papado y en general estaban exentos del control de los obispos ${ }^{18}$.

El papa Inocencio III, en 1199, dicta la conocida bula Vergentis in senium, pensada originariamente sólo para la ciudad italiana de Viterbo, donde equipara la herejía al crimen de lesa majestad (laessae majestatis divinae) ${ }^{19}$, sosteniendo que quien atenta contra Dios también lo hace contra la máxima expresión de poder, la Iglesia. Durante su papado, Inocencio III, también convoca al IV Concilio de Letrán que, en 1216, con un texto símil al de la bula Ad Abolendam, proscribe los juicios de Dios. Cabe aclarar que fue también este Pontífice el que anula la Magna Carta inglesa de 1215, alegándose el vicio de violencia.

Transcurrido el tiempo, existía cierta desconfianza por el accionar de los inquisidores, no sólo porque respondían únicamente ante el papado, sino por la ausencia de un procedimiento determinado y por los excesos cometidos como es el caso del cátaro converso llamado Roberto El Búlgaro (Robert Le Bougre), un dominico cuya brutalidad en la persecución de los herejes le vale el sobrenombre de "Martillo de los Herejes", o Malleus Haereticorum $^{20}$. Por esta razón, en 1229, en el Concilio de Tolosa se redactan cuarenta y cinco cánones que establecerían el procedimiento de investigación, enjuiciamiento y castigo de los casos sospechosos de herejía. Luego, en 1231, el papa Gregorio

18 Ibídem..., pp. 53-54. Ver también, nota al pie $\$ 96$ de lura novit curia, poder y verdad, p. 96.

19 Ceballos Gómez, Diana Luz, Política, heterodoxia e Inquisición, visible en: https://revistas. unal.edu.co/index.php/hisysoc/article/view/32322/32341

20 De la Torre, José Ignacio, Breve historia de la Inquisición, ob. cit., p. 56. 
IX dicta la bula Excommunicamus donde se procede a la excomulgación de diversos grupos heréticos. El procedimiento establecido por el Concilio de Tolosa de 1229 sería complementado en 1252 por la bula Ad Extirpanda del papa Inocencio IV, quien instaura con el canon veinticinco una nueva y horrenda era: el tiempo de la tortura como método para arrancar la confesión del acusado.

Formalizado -y legitimado en consecuencia- el procedimiento, los inquisidores continuaron su incesante labor persecutoria de la herejía, el sortilegio, la adivinación y la brujería. Caracterizaciones que en nuestros días recordarían los más vetustos tiempos del positivismo lombrosiano. La Iglesia se enorgullecía de la labor de sus inquisidores, al punto que varios lograron ser nombrados pontífices como el caso del inquisidor francés Jacques Fournier quien sería proclamado papa a fines de 1334, bajo el nombre de Benedicto XII.

Ahora bien, el denominado derecho común inquisitorial no sólo estaba compuesto por los cánones del Concilio de Tolosa y del derecho canónico ${ }^{21}$, sino también de manuales o instrucciones que lo interpretaban además de funcionar como guías prácticas basadas en la experiencia de sus autores. Así, pueden destacarse las Actas del Concilio Tarraconense de 1242, el Processus Inquisitionis (1244) de Bernardo de Caux y Juan de Saint Pierre, la Practica Inquisitionis Heretice Pravitati (1321), de Bernardo Gui, el Directorium Inquisitorum (1376) de Nicolás Aymerich reeditado en 1578, a pedido de la Santa Sede, con anotaciones del jurista español Francisco Peña y, por último, las Instrucciones (1484) de Tomás de Torquemada en la Inquisición española ${ }^{22}$. Sin tener en cuenta la obra de Torquemada,

21 Cabe mencionar que Bonifacio VIII dispone la prohibición de la derogación de normas que luchen contra la herejía. En idéntico sentido, el papa Clemente V, durante el Concilio de Viena, declara la imposibilidad de supresión de las leyes pontificias y conciliares contra los herejes, idea que también continuó Inocencio IV.

22 Ibídem..., p. 71. En 1478, el papa Sixto IV, a través de la bula Exigit sincerae devotionis, permite a los reyes españoles, Isabel y Fernando, nombrar inquisidores propios. Así, Tomás 
el texto más elocuente y jurídicamente relevante en su sentido procedimental era el propuesto por Nicolás Aymerich, texto que desarrollaré brevemente.

Evitándose poner el carro delante de los caballos es imperioso, antes de atreverse a pensar el juramento ex officio, o la solemnidad del secuestro de la palabra, conocer la ingeniería litúrgica. Por esta razón, explicaré, siguiendo la línea propuesta por Aymerich - Peña, sucintamente el procedimiento inquisitivo.

Según palabras de Aymerich - Peña ${ }^{23}$, el comienzo del proceso se daba por tres actos diferentes: la acusación, la denuncia o la encuesta. En el primer caso, el acusador (un tercero cualquiera, no el inquisidor, que considera que podía probar la herejía), valga la redundancia, podía actuar de tal, aunque quedando sometido a la ley del talión. En este sentido, el inicio por acusación podría resultar símil al actuar de las vindictas privadas actuales $^{24}$. En el segundo caso, un delator denunciaba a alguien por herejía o protección de la misma. Era el procedimiento habitual. En el tercer caso, no había confesión, acusación ni delación, sino rumor. El inquisidor, en consecuencia, actuaba de oficio, pudiéndose distinguir la encuesta general (inquisitio generalis) de la encuesta especial (inquisitio specialis).

Amén de ello, y en forma contemporánea, el proceso iniciaba con un sermón público realizado en lenguaje vulgar donde se apelaba a la conciencia -con una clara presión psicológica- de los habitantes de la zona afectada por herejía. Este sermón les concedía unos días de reflexión mientras se instalaba el tribunal inquisitorial. Era habitual que durante esos días de "reflexión" las personas se acercaran al tribunal a delatarse y pedir perdón -el tribunal sólo podía otorgar la absolución canónica, pero la

de Torquemada actuaba como el Inquisidor General de Castilla y era quien, en ese momento, resolvía las apelaciones de los condenados.

23 Aymerich, Nicolás; y, Peña, Francisco, El manual de los inquisidores, Ed. Muchnik editores, España, 1983, p. 135.

24 Según Francisco Peña, el papel de acusador era llevado por un «Fiscal», figura que llevaba adelante la acusación (ibídem..., p. 137). 
sacramental dependía del párroco-, o a denunciar a otros. Los sospechosos eran citados en la sede del tribunal donde, énfasis en este punto, se les tomaba juramento a los miembros del tribunal y al acusado. Así, el juramento del acusado, introducido por el papa Inocencio III, tomado ante los Santos Evangelios se denomina: jusjurandum de veritate dicenda o también llamado juramento ex officio ${ }^{25}$. Claramente, como desarrollaré, la solemnidad de la palabra invocada dista mucho del juramento ordálico.

El juramento ex officio era imprescindible en el ritual inquisitivo puesto que, no sólo se vinculaba a las pruebas argüidas en contra del acusado $^{26}$, sino que también se vincularía con la mecánica del ejercicio de la violencia física, psicológica y simbólica: la tortura ${ }^{27}$.

Posteriormente, José Ignacio de la Torre ${ }^{28}$ nos indica que se iniciaban una serie de audiencias siendo, por lo general, tres. En la primera, consistía en un activo interrogatorio del inquisidor que permitía expresarse al imputado. En la segunda, donde el acusado podía solicitar la asistencia de un defensor. Esta audiencia se condensaba en dos preguntas básicas: ¿se quiere defender de las acusaciones? ¿Tiene enemigos? Huelga aclarar que el defensor buscaba la confesión voluntaria y el arrepentimiento de la persona, pero de ninguna forma podía defenderla pues, sino también estaría defendiendo la herejía. Por otro lado, los testigos siempre eran secretos. En la tercera,

\footnotetext{
25 Según Aymerich, decía así: "Fulano de tal, con domicilio en..., habiendo sido denunciado y habiendo prestado juramento sobre el libro de los cuatro Evangelios, que tocaba con la mano derecha, de decir toda la verdad sobre sí mismo y sobre los demás, ha sido interrogado como sigue» (lbídem..., p. 142).

26 Transformándose en sospechoso vehemente de herejía (Ibídem...., p. 108). Vale recordar que existían tres tipos de sospecha: leve, fuerte o vehemente y violenta.

27 Los rituales judiciales se apuntalan a través de los componentes simbólicos. Según Aymerich, cuando se desarrollaba la primera audiencia -que ahora podría denominarse una indagatoria- la silla del acusado debía ser más baja y sencilla que el sitial del inquisidor (lbídem...., p. 144).

28 De la Torre, José Ignacio, Breve historia de la Inquisición, ob. cit., pp. 67-69.
} 
el tribunal comprobaba las manifestaciones del acusado y escuchaba los testigos de la acusación, quienes darían su visión.

Toda persona condenada debía sufrir el escarnio de los autos de fe, pero previamente debía abjurar por sus errores. Los autos de fe eran ceremonias públicas donde se manifestaba la adhesión a los postulados canónicos al tiempo que se condenaba la herejía, pudiéndose clasificar en generales, especiales, singulares y autillos. La ejecución de las condenas siempre quedaba en manos seculares, haya derramamiento de sangre o no. Así, vale aclarar que el proceso era concebido, viéndolo desde una visión moderna, para el utilitarismo, pues se procuraba el "bien público», mientras que las condenas a muerte tenían visos de prevención general negativa, aunque, para resguardar la fidelidad del análisis, conviene citar a Francisco Peña: “...hay que recordar que la finalidad primera del proceso y de la condena a muerte no es salvar el alma del acusado, sino procurar el bien público y aterrorizar al pueblo (ut alii terreantur)." 29 . El ritual implicaba una ceremonia de glorificación del poder público que tiende a la recomposición del orden del mundo y la reconstrucción de la soberanía política.

Ulteriormente, los papas León X y Adriano VI dictan las bulas Alias felices y Exponi nobis super fecisi tuam, respectivamente, donde se establece la Inquisición monástica en las tierras hispanoamericanas. Inquisición que luego sería reemplazada por el Santo Oficio, cuyos tribunales primeramente estuvieron emplazados en la Nueva España y el Perú, para agregarse finalmente el de Cartagena de Indias. La amplitud del territorio sometido a la jurisdicción inquisitorial hizo mella, hasta cierto punto, en su objetivo de conservar el statu quo.

En España, tras la caída de los reyes Carlos IV y Fernando VII, Napoleón a través de un decreto dispuso que su hermano José Bonaparte se transformara en el nuevo emperador ibérico,

29 Aymerich, Nicolás; y, Peña, Francisco, El manual de los inquisidores, ob. cit., p. 151. Cabe agregar que, el mismo Manual afirma que las cárceles debían ser terribles, ya que estaban concebidas más para el suplicio de los condenados que para su detención (Ibídem..., p. 237). 
cargo al que juraría en julio de 1808 bajo el nombre de José I de España. Al juramento del nuevo monarca le precedió la aprobación de una nueva Constitución conocida como el Estatuto de Bayona, el cual en su artículo 98 suprime los tribunales con "atribuciones especiales, y todas las justicias de abadengo". Finalmente, Napoleón decreta la abolición de la Inquisición el 4 de diciembre de 1808.

Igualmente, la Inquisición romana -creada en 1542 por el papa Pablo III mediante la bula Licet ad initio- aún existe bajo el nombre de la Congregación de la Doctrina de la Fe, la cual ahora tiene nuevas competencias; vale aclarar que fue fusionada con la Congregación del Índice, institución también creada por la mentada bula de Pablo III y que era la encargada de realizar los listados de libros prohibidos. La inquisición española, siendo la más significativa, tuvo un presagioso -y sinuoso- final. Así, ante la reposición de Fernando VII al trono español, supuso el regreso de la institución inquisitorial a mediados de 1814 para luego volver a ser suprimida durante la época del Trienio Liberal (1820-1823), donde ocurre su desaparición formal en 1821 a través de la aprobación de las Cortes Generales del Reino. Posteriormente, durante la denominada Década Ominosa del gobierno de Fernando VII vuelve a ser instaurada con sus atribuciones abiertamente menguadas. En 1834, durante la regencia de María Cristina de Borbón, viuda del monarca, y por decreto real la Inquisición española fue abolida definitivamente.

Habiéndose formalizado la supresión de la jurisdicción inquisitorial no importa necesariamente que la fuerza de su influencia no haya sido perenne. Según Gustavo Garibaldi ${ }^{30}$, el derecho romano canónico penetra en las tierras teutonas al punto de reemplazar las concepciones acusatorias preexistentes. En este sentido, el primer código penal alemán imperial fue la Constitutio Criminalis Carolina de 1532 que, a su vez, contenía reglas procedimentales; bajo una apariencia respetuosa del

30 Garibaldi, Gustavo E. L., Sistemas de juzgamiento de delitos en la Argentina, Ed. Ad Hoc, 2015, p. 15. 
acusatoria, la ideología inquisitiva era evidente. Así, por ejemplo, surgió la intervención del juez técnico junto a escabinos.

Las tierras galas también merecen su mención. Francia adopta el sistema inquisitivo mediante la ordenanza del rey Luis IX en 1254, la legislación posterior continúa esa senda en 1498 y 1539, en los reinados de Luis XII y Francisco I, respectivamente. En 1670, la ordenanza conocida como Code Luis (Luis XIV) significa, entre otras, la persecución penal ejercida por funcionarios del reino, distinguiéndose la question préparatoire de la question préalable, cuestiones ambas que fueron suprimidas en $1780 \mathrm{y}$ 1789, respectivamente ${ }^{31}$. En 1789, el Iluminismo, enamorado de los procesos acusatorios, inspira una nueva mixtura -inquisitivo reformado o anatema, según sea la visión considerada-: el Code d'instruction criminelle francés de 1808, año en que en España se jura el Estatuto de Bayona. Igualmente, recién en 1959 se prevé expresamente el principio de oportunidad en el proceso penal francés ${ }^{32}$. A partir de este código la indagatoria comienza a pensarse no sólo como un acto instructorio del proceso, sino como el ejercicio de un derecho. Una verdadera contradictio in terminis. Amén de ello, la supresión del juramento no significa la dispensa de ser sometido al interrogatorio por el magistrado; en otras palabras: al imputado no se le requiere que diga la verdad, pero sí que sea indagado. La obligación recae en asistir a la convocatoria, aunque guarde silencio o mienta; curiosa forma de pensar la indagatoria como un derecho.

Ahora, la atención debe mirar hacia el juramento ex officio; juramento que lamentablemente regresa con el proyecto de "Ley de la Mentira", presentado a inicios del mes de octubre por el presidente Ing. Mauricio Macri. Seguramente, la problemática del juramento inquisitivo sea más sencilla de explicar en la enquête que en su proyección sobre el trial.

31 Hendler, Edmundo; y Tedesco, Ignacio, La declaración del imputado y una perspectiva histórica comparada: la Justicia Criminal en Francia e Inglaterra en Sistemas procesales penales comparados, Ed. Ad Hoc, Buenos Aires, 2015, p. 395.

32 Garibaldi, Gustavo E. L., Sistemas de juzgamiento de delitos en la Argentina, ob. cit., p. 18. 
Según el maestro Ignacio Tedesco ${ }^{33}$, resulta innegable la influencia ejercida por los Bill of Rights en la Declaración de los Derechos del Hombre y del Ciudadano, adoptada por la Asamblea Francesa en 1789. Sin embargo, aclara, en su artículo noveno sólo se menciona: "todo hombre se presume inocente hasta que ha sido declarado culpable, y si se juzga indispensable arrestarlo, todo rigor que no sea necesario para asegurar su persona debe ser severamente reprimido por la ley". Sí bien la cláusula no enuncia la garantía de prohibición de autoincriminación, según interpretación, ésta es una consecuencia. Por su parte, el Iluminismo no centró su interés en el juramento ex officio, sino en las torturas que le vinculaban. Así, en 1786, en Toscana, se dicta la prohibición del tormento como herramienta para arrancar la confesión y el juramento inquisitorial. En 1788, en los Estados Generales se resuelve la abolición definitiva del juramento y la tortura. Binomio que siempre encuentra una íntima relación. El profesor Tedesco ${ }^{34}$ explica que la Asamblea Constituyente de la nueva Francia modifica provisoriamente el Code Luis de 1670. Este proceso de reformas concluye con la sanción de la Constitución de 1791, que deroga finalmente la ordenanza de Luis XIV.

Igualmente, no todo fue color de rosas. La abolición del juramento ex officio no significa el abandono del interrogatorio judicial ni siquiera en el Código de Instrucción Criminal francés de 1808. Incluso, la restricción de contar con un letrado defensor -uno que realmente efectuara actos de defensa y no que buscara la confesión voluntaria como aquel propuesto por Aymerich- venía ínsito en la legislación del ancien régime. Recién en 1897, con la sanción de la Ley Constance, se consagra el derecho a contar con un abogado defensor desde el interrogatorio inicial ${ }^{35}$. Huelga decir que, antes de la reforma

\footnotetext{
33 Tedesco, Ignacio, El privilegio contra la autoincriminación. Un estudio comparativo, en Cuadernos de Doctrina y jurisprudencia Penal No 6, Ed. Ad Hoc, Buenos Aires, 1997, p. 277-278.

34 Tedesco, Ignacio, El acusado en el ritual judicial, Ed. Didot, Buenos Aires, 2014, p. 301.

35 Ibídem..., p. 310.
} 
legislativa, los acusados debían declarar por su propia boca y sin consejo de persona alguna.

Una aclaración deviene necesaria: como se verá más adelante al contrastar los paradigmas, considero enfáticamente que no puede hablarse de adversarialidad si no existe igualdad real -no formal- entre los oponentes; Tedesco ${ }^{36}$ le da contenido a esta aseveración al considerar que la convocatoria a indagatoria importa una primera violencia ejercida, una violencia consistente en obligar al acusado a sentarse en el banquillo de los acusados. Violencia que, por un lado, atenta contra la presunción de inocencia, y por el otro, proscribe la posibilidad de hablar de la igualdad de posiciones propia del contradictorio -es mejor ni mencionar la existencia de sendos acusadores particulares- donde uno ya no puede ocupar uno de los vértices de todo conflicto, sino el centro de la escena.

En este punto, el plano latinoamericano se yergue. El Santo Oficio en tierras americanas tenía tres tribunales funcionando: Nueva España, Perú y Cartagena de Indias. Por otro lado, el derecho colonial estaba compuesto por las Siete Partidas, influenciadas por la Inquisición, completadas en 1265 durante el reinado de Alfonso I, siendo la Partida III la encargada de tratar las cuestiones procedimentales y la Partida VII, título treinta, el de los tormentos. El profesor Tedesco ${ }^{37}$ recuerda que fue la Asamblea del año XIII la que primero, el 24 de marzo, suprime la jurisdicción de la Inquisición limeña en el territorio argentino. Luego, el 21 de mayo, decreta la prohibición de los tormentos en conjunto a la inutilización de los instrumentos destinados a tales actos. Finalmente, el 9 de agosto, resuelve la supresión del juramento ex officio; el ciudadano Valle, al sustentar la propuesta, explica que: "exigir (del reo -el agregado es propio-) la verdad bajo juramento, es ponerlo en la dura alternativa de invocar el Santo Nombre de Dios para autorizar

\footnotetext{
36 Tedesco, Ignacio, El privilegio contra la autoincriminación. Un estudio comparativo, en Cuadernos de Doctrina y jurisprudencia Penal № 6, ob. cit., p. 281.
}

37 Ibídem..., pp. 271-272. 
la mentira, o de poner él mismo en mano del verdugo la duración de su existencia, violentando aquel axioma del derecho natural que dice nemo tenetur se ipsum prodere. Lo primero es un crimen de lesa divinidad; lo segundo es una infracción a los deberes que importa el amor a nosotros mismos; y ambos extremos obligan al hombre a ser impio, o cruel, o bárbaro o sacrílego, profanador del Eterno, o asesino de sí mismo. Ello es que si la filosofía de nuestro siglo ba desterrado felizmente el execrable uso de los tormentos... también debe probibir el juramento..." ${ }^{38}$. Estas concepciones fueron acompañadas por las legislaciones venideras.

Ahora bien, la interpretación jurisprudencial de la insipiente Corte Suprema argentina va continuar por esta línea, apartándose definitivamente de la lectura propuesta por su par norteamericana respecto del texto de la V Enmienda de la Constitución estadounidense que expresamente dice: "No person... shall be compelled in any criminal case to be a witness against himself'. Haciendo un breve repasado, en 1864, nuestro Máximo Tribunal sentencia tímidamente la primera causa bajo estos lineamientos in re "Mendoza" 39 . Casi un siglo después, en 1953, llegaría el caso "Oscar Rodríguez Pamias" 40 donde se reafirmaría la doctrina previamente sentada en "Mendoza". Finalmente, estando Alejandro Lanusse ocupando de facto el sillón de Rivadavia, la Corte Suprema, inflando pecho, se pronuncia orgullosamente in re "Diario El Atlántico" "11. Este último precedente, citando las disposiciones de la Asamblea del año XIII y doctrina constitucional, terminan por inclinar la balanza sobre la proscripción del juramento ex officio en los procesos penales argentinos.

\footnotetext{
38 Ravignani, Emilio, Asambleas constituyentes argentinas, T. I, p. 64. Puede verse en: http:// ravignanidigital.com.ar/asambleas/asa1/asa1110064.jpg

39 CSJN, "Criminal, contra Eduardo Mendoza, por falsificación de un manifiesto de Aduana" (Fallo, 1:350), 28/10/1864.

40 CSJN, “Oscar Rodríguez Pamia y Otro" (Fallo, 227:63), 19/10/1953.

41 CSJN, "El Atlántico" (Fallo, 281:177), 22/11/1971.
} 
Tal como puede advertirse, en el paradigma de la enquête el juramento y la tortura conformaban un binomio cuya funcionalidad litúrgica era arrancar las palabras del acusado; el ritual canónico pretendía la búsqueda de la confesión -la veridicción del imputado- para luego abjurarlo y concluir la ceremonia con el desarrollo del auto de fe en manos seculares. Así, el juramento inquisitivo sólo ocurre durante la misa judicial y no como requisito para acceder a ésta como sí sucede en el trial, donde el juramento aparece desdoblado: el juramento ordálico [I plead not guilty], por un lado, da paso a la puesta a prueba [jury trial], por el otro, y luego, en esta instancia, encuentra su manifestación concordante en el mutismo o la voz del acusado.

\section{El paradigma del trial: historia, procedimientos y juramentos}

Una vez más seguiré la senda oportunamente trazada en el Capítulo III de Iura novit curia, poder y verdad (\$3.2) para luego, distanciarme con particularidades propias de la presente investigación.

Los juicios de Dios, como ordalía carolingia, importaban auténticas puestas a prueba [épreuve] y no pruebas [preuve ${ }^{42}$ como algunos círculos académicos aún consideran. Según el profesor Robert Jacob ${ }^{43}$, las ordalías monoteístas proscriptas por el IV Concilio de Letrán fueron reemplazadas por el jury trial, cuyo veredicto de sus miembros significa la «palabra de verdad", el vere dictum, que continúa siendo la verdad bajada

42 El profesor Robert Jacob señala que son notables las distinciones idiomáticas del francés [épreuve y preuve] y del alemán [Beweis y Probe], en contraste con el italiano y el español cuyos términos proba y prueba conservan la ambigüedad propia del latín probatio. El profesor de la Université de Liège aclara que la terminología inglesa, influenciada por el law French y las estructuras originales del Common Law, acompañan la distinción lingüística con proof, trialy evidence (Jacob, Robert, Los modos rituales de resolución de los conflictos y la construcción de la verdad judicial (Antropología y Alto Medioevo occidental), en Derecho y Verdad II. Genealogía(s), ob. cit., p. 529).

43 Ibídem..., ob. cit., p. 556. 
del cielo. Seguramente uno de los escollos principales de la literatura jurídica pasa por pensar al jurado desde visiones meramente genealógicas, sin reparar en perspectivas antropológicas; equiparar el jurado romano al inglés resulta cuanto menos una ingenuidad. El jury trial guarda entonces importantes características ordálicas que lo estructuran como una puesta a prueba al punto, señala Jacob, que el sentido original de la palabra "trial" del verbo francés «trier", es ensayar o poner a prueba, conservado por el inglés to try.

Una vez más Germán Sucar y Jorge Cerdio Herrán ${ }^{44}$ proponen una minuciosa investigación que vale la pena profundizar. Los editores, consideran que el mundo anglófono hasta 1166 (año en que el rey Enrique II, padre de los también reyes Ricardo "Corazón de León" y Juan "Sin Tierra", instituye la Assize of Clarendon y los fundamentos del trial of indicment) el procedimiento penal disponía de dos instituciones implacables, conocidas también en las tierras galas, que consistían, la primera, en la ejecución sumaria de los malhechores capturados en flagrante delito, o en vías de escape; la segunda, denominada appeal of felony, donde el sospechoso era denunciado a las autoridades por la víctima y luego la determinación de culpabilidad era decidida a través de la ordalía de duelo.

Posteriormente, con el surgimiento de la Assize of Clarendon, resaltan los autores, se origina el trial of indicment del jury, aunque no era propiamente lo que se considera como jurado moderno. En efecto, en este contexto surge el sistema donde cada localidad obligaba a constituir un jurado que debía comparecer ante los jueces reales, quienes realizaban regulares visitas de vigilancia en los condados del reino, para informarles bajo juramento sobre la comisión de determinadas infracciones. En esta etapa, la Assize of Clarendon convivía con las ordalías que solían decidir normalmente el resultado de los

44 Sucar, Germán y Cerdio Herrán, Jorge, Introducción, en Derecho y Verdad II. Genealogía(s), ob. cit., pp. 116-119. 
juicios. La acusación propiciada por el jurado se denominaba indicment. En otras palabras, el jurado instituido, denominado Grand Jury, por la Assize of Clarendon no juzgaba, simplemente acusaba, el resultado de los pleitos se resolvía a través de los juicios de Dios. No resulta extraño que en estos días el Grand Jury norteamericano sea cuestionado por tener visos inquisitivos.

Para los editores, el surgimiento del jurado juzgador, también nombrado como el Petty Jury, ocurre después que el IV Concilio de Letrán, que inició en 1215 y terminó en 1216, condena y prohíbe los juicios de Dios. A partir de ahora, la liturgia procesal inglesa carecía de un medio que pusiera fin al pleito. Los magistrados, que coquetearon tan peligrosa como constantemente con el paradigma inquisitivo, propusieron interrogar a los jurados para obtener las informaciones necesarias para decidir la cuestión por ellos mismos. Finalmente, decidieron hacer intervenir un segundo jurado que determinaría la culpabilidad del acusado. Los albores del jury moderno, traen aparejados el reemplazo mecánico de la vox Dei de las ordalías carolingias, desde donde éste hereda su omnisciencia y la cohesión entre la quaestio facti y la quaestio iuris, por la vox populi de los miembros del jurado. Así, el trial como paradigma contemplará exitosamente las tres reglas aristotélicas para el teatro: el tiempo, el lugar y la acción; el ideal de la justicia espectáculo donde el motor son las partes y la verdad se genera en el estrépito del momento a través de la confrontación de dos puntos de vista sobre la realidad.

Recién en los siglos XVII y XVIII, el jurado moderno ganaría su conocida reputación de defensor incansable de las garantías y libertades públicas en razón de absolver, o atenuar las duras penas, a personas que el rey había perseguido por motivos políticos. A mediados del siglo XVIII el rol del magistrado del trial también se transforma; desde una actitud activa, donde era práctica común que los jueces manifestaran su opinión al jurado acerca de a quién debía favorecerse con la decisión, 
hasta un rol pasivo que se inicia con el desarrollo del adversary trial. Los magistrados, relegan su iniciativa sustituyéndola con la conducción del juicio, beneficiando la equidad entre los contrincantes $^{45}$.

Finalmente, merece la pena detenerse en la aparición de la figura del acusador público. Según Sucar y Herrán ${ }^{46}$ durante el transcurso de la primera mitad del siglo XIX el Parlamento inglés legisla la creación de una policía profesional cuya característica era su descentralización del gobierno central, con excepción de la Metropolitan Police de Londres. En ese contexto, no existía la figura del fiscal como actualmente se lo conoce. Por esta razón, la policía profesional, que había sido creada recientemente, asumía la responsabilidad de la persecución. En consecuencia, una vez más el paradigma del trial se acerca a la estructura del procès al fundirse las funciones investigativas y persecutorias en cabeza de un agente impensado: la policía; curiosamente, nuestros agentes fiscales comulgan entre sus atribuciones las funciones investigativas y acusatorias, que, en definitiva, los convierten más en los fiscales inquisitoriales pensados por Aymerich - Peña, que los propios del Commonwealth. La problemática más evidente era provocada por la descentralización. Así, intentando coordinar las políticas de las fuerzas policiales en materias persecutorias, en 1879, se crea la oficina del Director of Public Persecution que tenía por finalidad ayudar y aconsejar a las fuerzas policiales en materia de persecución criminal. Casi a finales del siglo XX, en 1985, el Parlamento dicta la Prosecution of Offenses Act que crea definitivamente la figura del Crown Prosecution Service, o Fiscalía General del Estado ${ }^{47}$.

\footnotetext{
45 Ibídem..., p. 128.

46 Ibídem..., pp. 129-130.

47 La cabeza de la Fiscalía General del Estado se encuentra a cargo del Director; funcionario público que es nombrado por el Parlamento a propuesta del fiscal general (attorney general) y responde a éste y a otros miembros del Ejecutivo, como el Government's Chief Law Officery el Minister for the Service. Ahora, su misión principal es revisar, y en su caso, continuar todas las cusas iniciadas por la policía (con excepción de ofensas menores, como faltas
} 
Ahora, deviene acuciante hacer algunas precisiones. Digamos que pensar que Inglaterra -y también Dinamarca- no fraternizó con el Santo Oficio es una verdad dicha a medias, como suele decirse; en realidad, sí bien la jurisdicción inquisitorial no estuvo presente formalmente, sí lo estuvieron algunas de sus prácticas. En otras palabras, la fuerza de la influencia inquisitiva se proyecta sobre la cosmovisión de la Inglaterra medieval, por ejemplo, en la implementación del juramento ex officio del acusado y, en menor medida, en infligir tormentos. Una vez más, el binomio. Cabe adelantar que finalmente la mixtura generada en el trial con el juramento inquisitivo es corregida a través de normas que formalizan prácticas acordes a la puesta a prueba judicial.

Previo a ingresar al estudio de los juramentos conviene identificarlos. Según Germán Sucar y Jorge Cerdio Herrán ${ }^{48}$, citando al profesor Robert Jacob, tras la prohibición de las ordalías carolingias en el mundo anglófono surge el jury trial, que, como puesta a prueba, continúa la modalidad de la intervención divina en la liturgia procesal, reconfigurándose simplemente. Así, el acto de juzgar en el trial conserva virtudes de verdad propias de los juicios de Dios, por esta razón, el carácter performativo de la fórmula: "I plead guilty", declaración del acusado, sin consistir en una explicación sobre el hecho atribuido, que crea por sí mismo el estado de culpabilidad obturando el ingreso a la puesta a prueba. Dicho de otra forma, en el marco de la audiencia de arraigo -momento en que inicia formalmente la persecución penal- el reconocimiento de culpabilidad genera tal estado y con ello se prescinde del desarrollo del juicio. En caso contrario, se conduce el proceso (lawsuit) hasta la etapa final (trial), donde el veredicto del jurado tiene para el juez idénticas consecuencias.

\footnotetext{
de tránsito), pero también, la misión de conducir los casos más importantes y complejos (Anitua, Gabriel Ignacio; Cappuccio, Emilio A.; y Zentner, Cynthia en El sistema procesal penal de Inglaterra y Gales en Sistemas Procesales Penales Comparados, ob. cit., p. 280).

48 Sucar, Germán y Cerdio Herrán, Jorge, Introducción, en Derecho y Verdad II. Genealogía(s), ob. cit., p. 138.
} 
Corresponde efectuar una advertencia: considerar que el jury trial es heredero de las ordalías carolingias no implica per se que sea una de estas en sentido estricto, sino más bien que antropológicamente posee características comunes, usos y prácticas embebidos dentro de una lógica -ideológicamente condicionada- interna. Ahora, ¿cuáles son las declaraciones? La primera, es aquella que brinda el acusado en la audiencia de arraigo, aunque sólo puede constituir el juramento ordálico -expresión formulada para diferenciarlo del decisorio y del ex officio- cuando manifiesta: "I plead not guilty", pues la solemnidad de la palabra enunciada por el acusado abre la puerta a la puesta a prueba [jury trial], lugar donde será sometida a decisión la tesis vociferada. La segunda, es la clásica declaración efectuada voluntariamente, previo consejo de su letrado de confianza, en la instancia del juicio y, donde a su vez, queda sometido al juramento de decir verdad. El juego entre las declaraciones y los juramentos resuelve satisfactoriamente la problemática suscitada otrora, donde el acusado enunciaba el juramento ordálico que daba lugar a la épreuve, pero mientras se desarrollaba la misma su declaración era sopesada como deficitaria. En otras palabras, los juicios de Dios -en general, eran unilaterales, salvo los combates que eran bilaterales- requieren no sólo igualdad entre los oponentes, sino también que la palabra traída por el acusado en la puesta a prueba sea pondera idénticamente como las contrarias, puesto que, en caso opuesto, existiría una discordancia entre la fuerza de tesis enunciada en la declaración performativa [declaración de inocencia] y aquella brindada entrado el ritual [que reafirma y sustenta la anterior]. Así, en este sentido, vale la pena repasar el camino seguido hasta la conformación de esta solución.

La Inglaterra medieval no demora demasiado en adoptar para sus prácticas judiciales el juramento ex officio establecido por el papa Inocencio III. Cabe decir que, para ese entonces, Inglaterra aún era profundamente católica hasta la Revolución 
Anglicana llevada adelante por el rey Enrique VIII ${ }^{49}$, en el siglo XVI. Curiosamente, los protestantes (calvinistas y luteranos) serían considerados herejes por Francisco Peña. Así, este juramento era implementado por dos cortes británicas: la Star Chamber (siglo XV) y la Courts of High Commission (siglo XVI). Estos tribunales exigían a las personas el juramento inquisitivo aun cuando no existían cargos contra éstas, instrumentalizando el juramento para iniciar el proceso.

Recuerda el profesor Tedesco ${ }^{50}$ que, en los juicios criminales existía la expectativa que el acusado tomara un rol activo, aun en su propio perjuicio. Incluso, era bastante habitual la dispensa del juramento, no por razones empáticas, sino más bien para evitar que el acusado lo utilice como medio de prueba de descargo. El juramento inquisitivo encuentra significativas afrentas en el Common Law. Así, según el profesor de la Universidad de Buenos Aires, en 1568 el juez Dyler, presidente de la Court of Common Pleas, concede un habeas corpus en un caso donde una persona había sido forzada a declarar bajo juramento; su fundamento central: el nemo tenetur seipsum prodere $^{51}$. Aunque, continúa el autor, fue el caso del editor John Lilburne el que obtuvo la repercusión necesaria. Lilburne fue arrestado e interrogado en la Star Chamber en 1637-1638 por

49 El hecho que el rey Enrique VIII haya roto relaciones con el Vaticano no significa que no compartiera ciertas prácticas. Así, en 1542 aprueba la ley de brujería, donde castigaba con la muerte la invocación de cualquier espíritu maligno. En 1597, Jacobo I, bajo influencia de las prácticas danesas, escribe el tratado de Demonología. Por último, en el siglo XVIII, es interesante destacar que el marqués Charles Cornwallis era profeso practicante de las torturas.

50 Tedesco, Ignacio, El privilegio contra la autoincriminación. Un estudio comparativo, en Cuadernos de Doctrina y jurisprudencia Penal N 6, ob. cit., pp. 267-269.

51 Sí bien no trataré la genealogía de la prohibición de autoincriminación, merece aclararse que Ignacio Tedesco agrega que circa 400 era hallada en la afirmación de San Crisóstomo en su comentario de la Epístola de San Pablo a los Hebreros cuando dijo: "No te digo que descubras eso -tu pecado- ante el público como una condecoración, ni que te acuses delante de otros" (Non tibi dico ut ea tamquam pompam in publicum proferas, neque ut apud alios te accuses) (Ibídem..., ob. cit., p. 260.). Asimismo, también está presente en el Talmud y en las enseñanzas de Rava. 
imprimir libros sediciosos en Holanda e importarlos a Inglaterra. Al ser interrogado bajo juramento, se rehúsa, razón por la cual fue multado y torturado. Ante esta situación, en 1640, en la primera reunión, el Parlamento presenta una petición para que fuera puesto en libertad, lo que consecuentemente ocurre. La Cámara de los Comunes resuelve en 1641 que la sentencia contra John Lilburne era ilegal, contraria a la libertad de la persona, sangrienta, malvada, bárbara y tiránica. Mientras que, cuando años después, la Cámara de los Lores establece que la sentencia debía ser anulada.

Igualmente, en 1641, el Parlamento inglés decide abolir tanto la Star Chamber como la Courts of High Commission, prohibiendo la administración del juramento inquisitivo ante la investigación de causas penales, aunque la reforma sólo era aplicable a los tribunales de la Corona, continuando la práctica de la interrogación previa al juicio hasta 1848. Tedesco concluye que, este hecho no significa que a partir del siglo XVIII la extracción involuntaria de respuestas fuese correcto. Igualmente, señala ${ }^{52}$ que una de las excepciones históricas al ius commune, que contemplaba el nemo tenetur, eran los casos de herejía, donde la gravedad de la falta se consideraba justificación suficiente para requerirle a cualquier persona que respondiera.

La prohibición de testificar por parte del imputado estaba basada en que en definitiva el acusado es parte interesada (¿acaso en nuestras latitudes, la supuesta víctima constituida como parte en el proceso no es interesada también?), aunque esta perspectiva cambia su rumbo cuando el Parlamento inglés en 1898 dicta la Criminal Evidence Act, norma que le reconoce al acusado la calidad de testigo, debiendo en consecuencia prestar el correspondiente juramento al declarar. Legislación que mal que pese, no fue vanguardista. Amén de ello, las palabras del acusado seguían generando problemas que, siguiendo a Ignacio Tedesco ${ }^{53}$, comenzaron a encauzarse recién con el

\footnotetext{
52 Tedesco, Ignacio, El acusado en el ritual judicial, ob. cit., pp. 297-298.

53 Ibídem..., pp. 307-308.
} 
reconocimiento del abogado defensor, liminarmente en 1696 con la sanción de la Treason Act para aquellos casos de traición, para luego ampliarse a las cortes criminales ordinarias hacia 1730; corrección que no provenía desde la normación, sino desde la práctica discrecional judicial. La aparición del abogado defensor cierra el círculo, el acusado puede por ello hablar sin ser compelido o, incluso, guardar silencio siendo defendido por su letrado.

Tal como aclaré, la Criminal Evidence Act de 1898 no fue vanguardista. En Estados Unidos no sólo no existía el juramento ex officio, sino que el derecho del acusado de declarar en calidad de testigo surge dos décadas antes, en 1878, mediante la Act of March $16^{54}$. Esta norma no sólo faculta al imputado a declarar en calidad de testigo en su propio juicio, sino que impide que la omisión de hacerlo genere algún tipo de presunción en contra.

Según Tedesco ${ }^{55}$, quien una vez más ilustra el camino, las prácticas norteamericanas implican una protesta contra los métodos inquisitoriales consistentes en interrogar a los acusados de forma manifiestamente injusta. Merece la pena recordar que, en el caso norteamericano, la prohibición de la autoincriminación primero estuvo presente en las constituciones estaduales para luego pasar a la Constitución federal en la V Enmienda;

54 En el diario de sesiones del Congreso norteamericano puede leerse: "CHAP. 37.- An Act to make persons charged with crimes and offences competent witnesses in the United States and Territorial Courts.

Be it enacted by the Senate and House of Representatires of the United States If America in Congress assembled, That in the trial of all indictments, informations, complaints, and other proceedings against persons charged with the commission of crimes, offences, and misdemeanors, in the United States courts, Territorial courts, and courts-martial, and courts of inquiry, in any State or Territory, including the District of FORTY-FIFTH CONGRESS. SESSI. II. 37, 38, 42, 43. 1878.

Columbia, the person so charged shall, at his own request but not otherwise, be a competent witness. And his failure to make such request shall not create any presumption against him.

Approved, March 16, 1878.". Visible en el siguiente link: https://www.loc.gov/law/help/ statutes-at-large/45th-congress/session-2/c45s2ch37.pdf

55 Tedesco, Ignacio, El privilegio contra la autoincriminación. Un estudio comparativo, en Cuadernos de Doctrina y jurisprudencia Penal No 6, ob. cit., p 260. El autor sigue la línea propuesta por el magistrado Brown in re "Brown v. Walker" (161 US., 591, 1896). 
así, puede hallárselo antes de 1650 en las colonias de Nueva Inglaterra y Virginia ${ }^{56}$.

En el mundo anglófono la prohibición de compeler al acusado a ser testigo contra sí mismo tiene una dimensión más extensa que el simple nemo tenetur. A diferencia de la enquête donde el imputado debe necesariamente sentarse en el banquillo de los acusados a dar explicaciones, pero puede negarse a declarar y/o está dispensado del juramento ex officio, en el trial el acusado no puede ser convocado a declarar, sus manifestaciones, que quedan sometidas al juramento de decir verdad por su calidad de testigo, son voluntarias y mayormente consensuadas con su letrado defensor. En otras palabras, no sólo el acusado puede negarse a brindar respuestas incriminatorias, sino que, también es libre de cualquier requerimiento ${ }^{57}$. El trial reconociendo la soberanía del ejercicio de la palabra en cabeza del acusado y eximiéndolo de requerimientos busca proscribir una verdadera problemática: the process is the punishment.

Este es el panorama sobre la declaración del acusado en la puesta a prueba [jury trial]. Así, como adelanté, el desarrollo de esta declaración resulta coherente con el sentido de la declaración performativa realizada por el acusado en la audiencia de arraigo; declaración que sometida al juramento ordálico habilita el juicio. Esta primera declaración, que la enquête carece, no suele ser observada con demasiada atención por nuestra literatura jurídica. Ahora, no puede soslayarse que, así como el juramento ex officio se vinculaba a la tortura, la declaración performativa tenía también un suplicio específico: la peine forte et dure ${ }^{58}$. La pena fuerte y dura, traducción del French Law, implicaba que sí una persona se obstinaba en no responder a la pregunta sobre su culpabilidad o inocencia en la audiencia de arraigo, con las características ordálicas que

\footnotetext{
56 Ibídem..., p. 269.

57 Ibídem..., p. 274.

58 Tedesco, Ignacio, El acusado en el ritual judicial, ob. cit., pp. 297-298.
} 
este momento procesal tiene, se la sometía a tormentos que no estaban destinados a arrancarle la confesión, sino otro tipo de declaración. Igualmente, infligir dolor sea por un motivo u otro -es decir, una disquisición cualitativa-, sigue siendo, en definitiva, el ejercicio del suplicio del hombre por el hombre. Así, la peine forte et dure tenía lugar una vez que había acusación formal ante el tribunal de enjuiciamiento y tenía por finalidad arrancar la palabra del acusado consistente en: «I plead guilty/ I plead not guilty".

Según el historiador británico John Jenkins ${ }^{59}$, en Inglaterra el Statute of Westminster de 1275 determinaba que el castigo era consistente en el encarcelamiento e inanición hasta la sumisión del acusado, pero legislación de 1406 agregaba que sea aplastado por grandes pesos hasta la muerte. Una condena era equivalente a la pérdida de bienes, así que muchas personas decidían someterse a la peinte forte et dure para que sus familiares puedan heredarlos. Mientras que, en Estados Unidos, uno de los casos más resonantes ocurre tras su implementación durante los juicios de brujería de Salem de 1692. Casos así sirvieron de fundamento para la posterior prohibición constitucional de castigos crueles e inusuales.

\section{La fuerza de la palabra: los juramentos}

Aunque sea sintético, hay que reparar en este punto. Así, cabe interrogarse, ¿qué son los juramentos? Según Tedesco ${ }^{60}$, citando a Alain Testart, el juramento es un acto de la palabra, a la par que también un acto de sacrificio eficaz. El juramento está íntimamente vinculado con la idea de sanción, ya sea de carácter sobrenatural, social o meramente jurídica, etc., suscitado en forma inmediata o diferida ${ }^{61}$.

\footnotetext{
59 https://www.britannica.com/topic/peine-forte-et-dure

60 Tedesco, Ignacio, El acusado en el ritual judicial, ob. cit., p. 283.

61 Según Robert Jacob, la puesta a prueba es típicamente aquella que se puede analizar indistintamente como juramento u ordalía. Siendo juramento, ocurre cuando la sanción
} 
Entonces, ¿cuáles son sus funciones? El acento, lo relevante, está puesto entre la solemnidad que instituye las palabras enunciadas -más que en su contenido en sí- y las fuerzas emplazadas. En otras palabras, la función mira la relación existente entre quien invoca el juramento y la sacralidad invocada. Así, pueden advertirse dos partes del juramento: la primera, la divinidad convocada como garantía y la imprecación, el sometimiento del jurador a la sanción, v. gr., la cólera divina, sí miente o falta a su promesa ${ }^{62}$. Por esta razón, tanto tribus africanas como en la antigüedad existían ciertas suspicacias ante las fuerzas llamadas a decidir. Jacob correctamente explica que una fuerza demasiado familiar, excesivamente cercana y protectora del que jura resulta sospechosa para el adversario y no constituiría un garante eficaz; razón por la cual los juramentos promisorios y judiciales se diferencian ${ }^{63}$.

Asimismo, el profesor de la Universidad de Liège ${ }^{64}$ aclara que, en realidad, no existen los ritos decisorios mudos, sean juramentos u ordalías. Ambos implican procesos de confrontación de dos pretensiones antagónicas y, en tanto constituyen una forma de resolución de conflictos, reposan sobre el principio que una tesis debe ser validada sobre otra. Ordalías y juramentos, enfáticamente, son test que vuelven decisivas la palabra solemne.

Los juramentos no sólo integran los rituales, sean judiciales o religiosos, sino también que legitiman estructuras. Así, la enquête funcionaba con dos juramentos diferentes que tenían un denominador común: la invocación del Dios verdadero

divina es diferida, v. gr., la evolución posterior de la salud o la fecundidad de la mujer verificará la sinceridad de las palabras. En cambio, la sanción de las ordalías ocurre en forma inmediata pues, las son sentencias en per se. En consecuencia, la épreuve puede endentarse en ambos sentidos (Jacob, Robert, La gracia de los jueces. La institución judicial y lo sagrado en Occidente, ob. cit., p. 120).

62 Tedesco, Ignacio, El acusado en el ritual judicial, ob. cit., p. 284.

63 Jacob, Robert, La gracia de los jueces. La institución judicial y lo sagrado en Occidente, ob. cit., pp. 100-101.

64 Ibídem..., p. 34. 
como garante. El primer juramento, quizás más opacado, era prestado por los integrantes del tribunal inquisitorial, quienes, ante la fuerza llamada, Dios en este caso, juraban combatir la herejía. El segundo, el más conocido: el juramento ex officio del acusado que no sólo contenía una coerción física y psicológica, sino también moral. Las sociedades europeas medievales eran profundamente religiosas y temerosas a la ira divina tanto o más que a los tormentos terrenos. Callar o negar las herejías, o el conocimiento de éstas, traía aparejado no sólo sanciones jurídicas -penas de prisión o muerte, siempre ejecutado a través de autos de fe por manos seculares-, sino también religiosas: la interdicción o la excomunión. La interdicción prohíbe la celebración de misas y la administración de sacramentos, sólo permitiéndose los bautismos y extremaunciones, mientras que la excomunión cortaba el lazo divino entre Dios y la persona excomulgada; por ejemplo, cuando el papa Inocencio III decide en 1209 excomulgar al rey Juan I de Inglaterra, conocido como "Sin Tierra" tras haber perdido el Ducado de Normandía, genera que los juramentos de vasallaje pierdan todo valor y su autoridad se desvanezca.

Acaece una problemática epistemológica impensada cuando se establece la prohibición del juramento inquisitorial, pues, esta dispensa no logra deslegitimar la ingeniería procesal, sino que reconfigurada ésta se asienta en la reafirmación de la asimetría de las partes. En otras palabras, el vacío dejado tras el retroceso del juramento (solemnidad-sanción) acentúa la proyección de la sospecha (leve, vehemente o violenta), que precedía a la declaración juramentada, pero esta vez sobre el contenido de la palabra enunciada. La proscripción del juramento ex officio no hiere de muerte al proceso inquisitivo puesto que, esta solemnidad no era condición para el desarrollo litúrgico, como si ocurre en el trial con el juramento ordálico, máxime, tampoco tenía en miras el equilibrio de los oponentes, pues siempre actuaba en sentido conminatorio.

Distinto ocurre con el jury trial. Actualmente puede señalarse la intervención de por lo menos cuatro juramentos distintos. 
El primero, corresponde al del magistrado. El segundo, el asumido por el jurado; aquí existen dos momentos diferentes: según Harfuch ${ }^{65}$, en la audiencia voir dire (sea, "decir verdad" o "ver qué dicen") los jurados están obligados a decir la verdad de todo aquello que le interroguen, jurando inicialmente como cualquier testigo; posteriormente, una vez conformado el panel definitivo de jurados, tanto titulares como suplentes, asumen nuevo juramento sobre sus funciones (conforme el artículo 342 bis del Código Procesal Penal de la Provincia de Buenos Aires). Digamos entonces que estos dos primeros actúan como juramentos de legitimidad de las personas intervinientes.

El tercero, el juramento ordálico encarnado en la declaración performativa: "I plead not guilty». Ahora bien, el acusado que se declara culpable en la audiencia de arraigo crea ipso iure el estado de culpabilidad, razón por la cual se prescinde del desarrollo del juicio. Sólo puede hablarse del juramento ordálico cuando existe una acusación formal contra el acusado y éste, en el marco de la audiencia de arraigo, manifiesta su inocencia. Esta declaración performativa constituye por esencia el juramento ordálico que da lugar a la puesta a prueba judicial [jury trial] y que, también traza el rumbo de la estrategia defensista.

Vale aclarar que las normas procesales no establecen ni exigen que la declaración performativa sea juramentada, sino que el juramento [que habilita el ritual] está ínsito en la palabra del acusado en virtud de la herencia ordálica que empapa al juicio por jurados propio del mundo anglófono.

El último, los juramentos asumidos tanto por los testigos como por el acusado. Esto encuentra su lógica en que trial no conoce otras pruebas que no sean las testificales. Dicho de otra forma, la prueba producida durante el ritual debe ser verbalizada.

65 Harfuch, Andrés, El juicio por jurados en la provincia de Buenos Aires, ob. cit., p. 167. 


\section{Sistemas procesales comparados: el jury trial $y$ la question}

En esta instancia, desde una visión etnológica, conviene plasmar en regímenes procedimentales concretos los conceptos hasta ahora desarrollados. La idea es otorgar mayor visibilidad al contraste procesal. Veamos.

\section{a. El plano anglófono}

Iniciaré con el proceso penal made in England. El derecho inglés carece de un código procesal como acostumbra el derecho continental, siendo la dispersión normativa una característica distintiva de este proceso penal. Así, merece destacarse: la Police and Criminal Evidence Act (Codes of Practices) [1984]; la Prosecution of Offences Act [1985]; The Code for Crown Prosecutors (The Code) [1986]; la Human Rights Act [1998]; la Criminal Justice Act [2003]; y el Criminal Procedure Rules [2010], por nombrar algunos. Describiré las principales características de las normas mencionadas.

La Police and Criminal Evidence Act de 1984. Según el profesor Juan Damián Moreno ${ }^{66}$, catedrático de la Universidad Autónoma de Madrid, esta norma está inspirada en el informe realizado por la Comisión Phillips en 1981. Existía un reproche generalizado en la acumulación de funciones investigativas y acusatorias encabezadas en la figura de la policía, creada durante la primera mitad del siglo XIX. Esta circunstancia dio lugar muchas veces a que, en el empeño por lograr una condena del sospechoso, no se guardara la neutralidad e imparcialidad necesaria, llevándose procesos vindicativos e incluso ocultándose aspectos beneficiosos para la defensa. Por lo tanto, se concluye que la acumulación de funciones, investigativas y acusatorias, desequilibra la posición existente entre la acusación y la defensa que constituye el eje fundamental del sistema

\footnotetext{
66 Moreno, Juan Damián, La decisión de acusar. Un estudio a la luz del sistema acusatorio inglés, Ed. Dykinson, Madrid, 2014, pp. 33-34.
} 
acusatorio. En consecuencia, la Police and Criminal Evidence, o el Codes of Practices, pretende limitar estos excesos policiales al imponer protocolos de actuación al investigar los delitos.

La Prosecution of Offences Act de 1985. Merece la pena recordar que la policía contaba desde 1879 con la oficina del Director Of Public Persecution que tenía por finalidad ayudar y aconsejar a las fuerzas en materia de persecución criminal. En Inglaterra, si bien existía el cargo de Attorney General (Procurador General), no existían los fiscales propiamente dichos. Entonces, ante este escenario efervescente, el Parlamento ingles crea en 1985 la figura del Crown Prosecution Service a instancias de la Prosecution of Offences Act que entra en vigencia en $1986^{67}$. El acusador público inglés tiene una función netamente procesal y no investigativa, comunión que aún ocurre en Argentina, por ejemplo. Así, la figura encargada de investigar continúa siendo la policía, que no recibe instrucciones de nadie con independencia de las autorizaciones necesarias que deba solicitar en el transcurso de las investigaciones ${ }^{68}$. Por esta razón, consideran que el sistema procesal inglés resulta plenamente contradictorio y tiene naturaleza adversarial.

The Code for Crown Prosecutors (The Code) de 1986. Es un protocolo actualizado asiduamente que dicta el Director of Public Persecution, en función del artículo 10 de la Prosecution of Offences Act de 1985, para decidir el mérito de acusar en cada caso en particular según evaluaciones probatorias y de perspectivas reales de condena.

La Human Righs Act de 1998. Impone la obligación tanto a los jueces como al resto de los poderes públicos de adaptar sus decisiones a los principios aplicados de la Convención Europea de Derechos Humanos por el Tribunal de Estrasburgo.

\footnotetext{
67 Hendler, Edmundo, Derecho Penal y Procesal Penal de los Estados Unidos, Ed. Ad Hoc, Buenos Aires, 2006, p. 160.

68 Moreno, Juan Damián, La decisión de acusar..., ob. cit., pp. 64-65. Incluso, el autor entiende que la acusación pública no implica el ejercicio de autoridad, remarcándose la incompatibilidad entre la función de castigar y la de acusar (ibídem..., pp. 68-69).
} 
La Criminal Justice Act de 2003. Diversas problemáticas hicieron que una vez más la cultura judicial anglosajona se vea seducida por los jueces de instrucción propios del sistema inquisitivo $^{69}$. Así, tras la publicación del Libro Blanco en 2002, nacido a propuesta de la Comisión Auld, se dicta la Criminal Justice Act bajo el eslogan "Justice for all". Esta norma ofrece un nuevo marco legal para víctimas y testigos y, a su vez, aumenta el protagonismo de las Magistrates' Courts en desmedro de los jurados ${ }^{70}$.

El Criminal Procedure Rules ${ }^{71}$ de 2010. Tiene una estructura símil a un código procesal penal. El artículo 1.1 establece como objetivo fundamental el garantizar a las partes un juicio justo. Ahora bien, lo auténticamente relevante para este trabajo está legislado en esta norma: la declaración performativa. Particularmente, se encuentra en el juego armónico de los artículos 9.8 a 9.10.

En Inglaterra la declaración performativa se realiza ante las Magistrates' Courts. Así, el artículo 9.8 establece los estándares para realizar la declaración: edad, competencia y presunción. El primero, debe tratarse de una persona mayor de 18 años la que efectúe la request for plea. El segundo, la competencia queda sometida a condición de la declaración de culpabilidad o inocencia y al delito atribuido. Por último, sí el sospechoso se negare a contestar, en vez de aplicar el castigo denominado peine forte et dure, como oportunamente mencioné, se presume la negativa enviando el caso a juicio ${ }^{72}$.

Según Moreno $^{73}$, la declaración de culpabilidad no excluye la pena, sí el juicio. Ahora bien, el acusado puede tener la expectativa

69 Según Moreno, la influencia del tacherismo y del blairismo, al igual que el informe Leigh y Zedner (1992), inclinaron la balanza hacia la incorporación del juge d'instruction, aunque posteriormente la idea fracasa (Moreno, Juan Damián, La decisión de acusar..., ob. cit., p. 31).

70 Ibídem..., p. 54.

71 Disponible la última versión -abril de 2019- en: https://www.justice.gov.uk/courts/procedurerules/criminal/docs/2015/criminal-procedure-rules-practice-directions-april-2019.pdf

72 Ver Santa Pinter, José Julio, Sistema del Derecho Anglosajón, Ed. Depalma, Buenos Aires, 1956, p. 93.

73 Moreno, Juan Damián, La decisión de acusar..., ob. cit. p. 106. 
razonable que le reduzcan la pena en función de los criterios de imposición (sentencing guidelines). La declaración de culpabilidad está prevista en el artículo 9.9, mientras que la de inocencia en el siguiente, el artículo 9.10. Este artículo, en general, contiene reglas sobre la determinación de competencias, ya sea la de las Magistrates' Courts o de las Crown Court, introduciéndose como elemento objetivo para su ponderación el monto de $\$ 5,000$.

En Estados Unidos, la audiencia de arraigo -o arraigment- es la oportunidad procesal para que el acusado se entere formalmente de los cargos y se declare culpable o inocente. El profesor Hendler ${ }^{74}$ advierte que en la Inglaterra medieval esta audiencia se desarrollaba en cuatro pasos: 1.- Se le llamaba al prisionero para que levantara su mano a forma de identificación; 2.- Se le leía la acusación en inglés traducida del latín; 3.- Se le requería al acusado que se declarara culpable o inocente, bajo sanción de peine forte et dure en caso de silencio; y, 4.- Se le preguntaba la forma en la que quería ser juzgado encontrándose diversas posibilidades de los juicios de Dios. Actualmente, señala el profesor, estos pasos fueron superados, incluso se adopta idénticamente la presunción del silencio que surge del Criminal Procedure Rules, aunque algo es claro, la audiencia debe desarrollarse de cualquier manera.

Las declaraciones vigentes habilitadas son: culpable, no culpable o inocente, no culpable por insania y nolo contendere $\mathrm{o}$ non vult contendere o non vult. Así, cabe reconocer que sólo las dos primeras son comunes a todas las jurisdicciones.

En estos tiempos la mayoría de los casos terminan en declaraciones de culpabilidad, el jury trial está en franca retirada poniendo en jaque la herencia ordálica introducida en el paradigma acusatorio, aunque la participación popular, por lo menos, queda garantizada con las integraciones populares que suelen darse en las Magistrates' Courts ${ }^{75}$.

\footnotetext{
74 Hendler, Edmundo, Derecho Penal y Procesal Penal de los Estados Unidos, ob. cit., pp. 195-196.

75 En Estados Unidos, los juicios por jurados vienen en franca retirada gracias a las declaraciones de culpabilidad (acuerdos con las Fiscalías), aunque en 2018 se registró un alza del
} 


\section{b. El plano continental: el caso argentino. El funcionamiento anómalo de nuestro jurado. El proyecto de "Ley de la Mentira"}

Merece formularse una advertencia previa. En este acápite trataré con procesos penales argentinos en forma indistinta, aunque me inclinaré especialmente por aquellos donde esté prevista la intervención de los jurados, y me permitiré obviar los preámbulos e ir directo al punto. Amén de ello, no resulta ocioso remarcar que el paradigma imperante en la República Argentina es la enquête, en virtud de los motivos históricas y antropológicos oportunamente esgrimidos. Ahora, dentro de esta cultura judicial corresponde precisar que en mayor o menor medida los procedimientos son mixtos o inquisitivos reformados, pero nunca acusatorios ${ }^{76}$.

Nuestros procesos mixto-reformados herederos del paradigma romano canónico carecen del sentido lúdico -o de justicia espectáculo- propio de las puestas a prueba del mundo anglófono. Así, el imputado suele tener la oportunidad de declarar varias veces, pensando esta declaración como el ejercicio

4\% en relación a los últimos años (https://www.uscourts.gov/statistics-reports/us-districtcourts-judicial-business-2018). Las declaraciones de culpabilidad, que crecieron un $6 \%$ en relación a 2017, son elegidas por los acusados pues, les permiten negociar una condena con Fiscalía siendo mucho menos gravosa que la dictada en el jury trial. En Inglaterra, la "conviction rate" o tasa de condena contempla el factor discriminación racial (ver Thomas, Cheryl, Exposing the myths of jury service en Criminal Law Review, Vol.: 415, Issue: 6, Sweet \& Maxwell, Editor lan Dennis, Inglaterra, 2008).

76 Someramente, puede decirse, sin caer en desatino, que mientras exista la etapa instructoria en sí; la actuación de jueces de instrucción y los fiscales investigadores-acusadores; la audiencia indagatoria (subrepticio enamoramiento por la confesión); la disociación entre la quaestio facti y la quaestio iuris; el nemo tenetur pensado desde las visiones inquisitivas; los acusadores particulares; el culto propio al papel y los sellos (preservación temporal); la congruencia facto jurídica; ciertas valoraciones probatorias inclinadas hacia la prueba tasada; el instituto de la nulidad (¡no confundir con la regla de exclusión!); la aplicación del brocardo iura novit curia en la etapa de juicio; el recurso acusador ante absoluciones; la oralidad actuada; la búsqueda de la [mal] denominada verdad real [alétheia clásica, correspondencia]; el proceso discontinuado en acción, tiempo y lugar; la concepción de recomposición del orden mundial y la soberanía vulnerada; el principio de legalidad penal; entre otro centenar de reglas que hacen a la liturgia, mal puede pensarse estar en otra vereda. Corresponde hablar de mixturas que tampoco son paradigmas en el sentido kuhniano. 
de un derecho desde la sanción, en 1808, del famoso Code d'instruction criminelle. El acusado declara en indagatoria, con independencia del nombre que pueda tener este acto procesal en una u otra jurisdicción. A diferencia del trial, no existe la posibilidad que, ante una declaración voluntaria inculpatoria, se prescinda del juicio. Lógicamente, la excepción está constituida por los clásicos medios alternativos, la suspensión del proceso a prueba y el juicio abreviado. En líneas generales, la regla es el desarrollo del juicio. Traduciéndolo: nuestros procesos no están estructurados como puestas a prueba, ergo carecen de la declaración performativa. Técnicamente hablando, no podría accederse al jury trial sin el juramento ordálico que justamente se da ante la declaración performativa negativa. Ahí ya existe una irregularidad suficiente que no sólo afecta la legitimidad del ritual, sino que también su funcionamiento. El proceso trata de ser reconfigurado de uno [enquête] en otro [trial] sin la llave que permite ese cambio.

El problema surge cuando se pretende equiparar inconmensurables, siguiendo la línea propuesta por el filósofo norteamericano Thomas Kuhn en su increíble libro Las revoluciones científicas. Ni los procesos son sólo códigos procedimentales, ni una indagatoria del procès resulta idéntica a la declaración testifical del acusado en el Common Law. Así, el simple requerimiento para sentarse en el banquillo de los acusados hiere de muerte cualquier expectativa de igualdad real, amén que es cierto que los códigos intentan eliminar el imperativo y convertirlo marcadamente en el ejercicio de un derecho, v. gr., artículos 258, C.P.P. de Buenos Aires; 198 del C.P.P. de Río Negro; 203 del C.P.P. de Neuquén; 321 del C.P.P. de Chubut, con excepción del artículo 385 del C.P.P. cordobés que aún conserva el sentido obligatorio de la declaración indagatoria en etapa de debate. Igualmente, la existencia propia de jurados escabinados deviene per se conflictiva desde su implementación en la Constitutio Criminalis Carolina de 1532. Según Moreno ${ }^{77}$,

77 Moreno, Juan Damián, La decisión de acusar..., ob. cit. p. 81. 
debido al efecto negativo que ocasiona en la fama o reputación de una persona el hecho de ser citado ante un tribunal para responder una imputación, se considera que the process is the punishment; por esta razón, los fiscales sólo están autorizados a acusar cuando hayan superado un riguroso control de calidad que trate de evitar acusaciones arbitrarias, infundadas o injustificadas: el "Full Code Test» bajo los parámetros establecidos en The Code.

Entonces, cabe resaltar la inequivalencia manifiesta entre la declaración indagatoria propia de nuestro sistema, donde el acusado queda dispensado del juramento ex officio, respecto de las declaraciones performativa y testifical brindadas en el trial. Mientras que las declaraciones del mundo anglófono guardan su coherencia litúrgica, la declaración desarrollada en nuestras latitudes sigue mirando la búsqueda de la confesión como legitimadora del proceso. En definitiva, son dos visiones disímiles de la construcción de la verdad judicial.

Estas singularidades descriptas conllevan a que el jurado argentino funcione anómalamente. Pero, ¿qué sería la anomalía? El concepto no corresponde a la idea kuhneana de anomalía paradigmática. Sino, una noción epistemológica por ahora vaga y nebulosa: la ausencia de expectativas que el ritual funcione conforme fue estructurado. La existencia de veredictos de culpabilidad o inocencia no significa mecánicamente el correcto funcionamiento litúrgico, sino que tras el cumplimiento de una serie de pasos se logra un resultado "x". La clave está en el análisis de ese resultado. Los veredictos, ¿son correctos? Las incongruencias epistémicas, ¿influyen en la resolución de los casos? Los trabajos de campo son fundamentales para brindar luz al misterio.

Recientemente, por el INECIP ${ }^{78}$ (Instituto de Estudios Comparados en Ciencias Penales y Sociales) fueron informados

\footnotetext{
78 Porterie, Sidonie y Romano, Aldana, El poder del jurado: Descubriendo el juicio por jurados en la provincia de Buenos Aires, Ediciones del INECIP, Ciudad Autónoma de Buenos Aires, 2018, p. 33 y ss.
} 
datos oficiales pertenecientes a la Suprema Corte de Justicia de la Provincia de Buenos Aires. La línea temporal relevada fue de 2015 al 2017. Las cifras arrojaron el aumento de los juicios por jurados de 38 a 77, donde la tasa de condena fue del 64\%, excluyéndose los "veredictos mixtos". En todos los años la tasa de condena fue superior a los veredictos de no culpabilidad del jurado. Desgraciadamente, este estudio no contempla los factores de discriminación como sí lo hacen en Inglaterra. Cabe llamar a la reflexión, pero a su vez cuestionarse, sí los resultados de las cifras relevadas responden a la anomalía aludida previamente.

Una aclaración que iba ser una ingenuidad se transforma en pesadilla. Partir de falsas premisas puede llevar a cometer errores conceptuales evidentes; considerar en estas tierras estar en presencia del paradigma acusatorio en vez del inquisitivo reformado es el perfecto ejemplo. Peca de incauta la persona que piensa que reinstaurar el juramento ex officio puede corregir los déficits epistémicos actuales de nuestro jury trial criollo, pero como el padre de Hamlet que regresa de la tumba, el juramento inquisitivo ahora desempolva los hábitos.

La primera semana de octubre el representante del Poder Ejecutivo, Presidente Ing. Mauricio Macri, presentó ante la Cámara de Diputados el proyecto de ley denominado "Ley de la Mentira"79 (Expediente Diputados $N^{\circ}$ 0006-PE-20), junto con las firmas del Jefe de Gabinete, Marcos Peña, y los ministros, Germán Garavano del Ministerio de Justicia y Derechos Humano, y Patricia Bullrich, titular de la cartera de Seguridad.

El proyecto en cuestión actúa sobre dos frentes: el sustantivo y el adjetivo, desdoblándose en este último caso. Concretamente, se pretende la modificación del Código Penal argentino (Ley 11.179), del Código Procesal Penal de la Nación (a continuación: "Código Levene", según Ley 23.984) y del Código

\footnotetext{
79 Proyecto disponible en: https://www.diariojudicial.com/public/documentos/000/086/593/ 000086593. pdf?fbclid=IwAR1 vrMTYxA-8vxJ0vrm5zIxc1zm-V7eX-Sc809-DRfiK5ALful$055 f z c z \mid$
} 
Procesal Penal Federal (a continuación: "Nuevo C.P.P.F.", según Ley 27.063 con más Decreto 118/2019).

Respecto del Código Penal argentino, el proyecto de ley, en su artículo $1^{\circ}$, establece la modificación del artículo $275^{\circ}$ (Capítulo XII, del Título XI: Delitos contra la administración pública) que pena el falso testimonio. Sí bien se mantiene la escala penal, se agrega a su vez la pena de multa la cual es determinada entre: $\$ 96.000$ a $\$ 300.000$. El tipo penal, a su vez, exige ser parte de un proceso judicial o administrativo, reemplazándose así la denominada "autoridad competente".

En el siguiente párrafo, califica nuevos sujetos pasibles de cometerlo: abogados, testigos, peritos e intérpretes respecto de las deposiciones, testimonios, traducciones o informes. Por último, se dispone el agravante respecto del primer y segundo párrafo si fuera cometido en causa penal en perjuicio del acusado.

El cuarto párrafo resulta más confuso que relevante, dispone: "La misma pena del párrafo primero se impondrá al imputado que, habiendo sido convocado legalmente a prestar declaración, en su deposición a sabiendas afirmare una falsedad o negare la verdad que conoce, en todo o en parte. Para ello, previamente debe haber sido impuesto de las garantias constitucionales que le asisten y haber manifestado de forma expresa su voluntad de declarar.

En todos los casos se impondrá al reo, además, inhabilitación absoluta por doble tiempo de la condena".

Básicamente, el proyecto pretende la reinstauración del juramento ex officio esta vez condicionada a la manifestación positiva de declarar con las suspicacias que ello implica. Tal como se vio, no existe equiparación interpretativa posible entre la extensión otorgada al nemo tenetur en el trial con la contenida en este proyecto. Cabe aclarar, una vez más, que el mundo anglófono le permite al acusado ser testigo en su propia causa penal [producción de prueba], pero esta declaración sometida a juramento debe ser voluntaria, previa recomendación de su abogado. En otras palabras, el acusado no sólo no está obligado 
a autoincriminarse -incluso, el silencio tampoco puede ser valorado en su contra, aunque luego haga uso de la palabra-, sino que ni siquiera puede ser obligado a sentarse en el banquillo de los acusados. Es decir, comprende también los requerimientos.

Los visos inquisitivos pueden vislumbrarse incluso en la formulación símil con el Manual de Aymerich y Peña, donde los abogados defensores buscaban la confesión voluntaria y el arrepentimiento del sospechado de herejía, pero de ninguna forma podían defenderla, pues, sino también estarían defendiendo la herejía. Por último, se mantiene la inhabilitación absoluta dispuesta al final del artículo -con una deficiente técnica legislativa- que deja serias dudas: ¿sobre qué recaería la inhabilitación? ¿Sobre la palabra del imputado? ¿Es una pena accesoria del delito atribuido? ¿Y sí ese también posee inhabilitación? Entre otras. Vale destacar que la calidad de testigo es inherente a la persona y no una actividad reglada.

Respecto del Nuevo C.P.P.F., el proyecto de ley trata el asunto entre los artículos $3^{\circ}$ y $6^{\circ}$. Así, el texto proyectado en el artículo $3^{\circ}$ sustituye el texto del artículo $4^{\circ}$ de la norma ritual agregando el juramento ex officio cuando el imputado "decida declarar".

Por otra parte, el artículo $4^{\circ}$ modifica el texto previsto en el artículo $70^{\circ}$ : "Libertad para declarar". El primer párrafo expresa: "Las citaciones al imputado no tendrán por finalidad obtener una declaración sobre el hecho que se le imputa, pero éste tendrá la libertad de declarar cuantas veces quiera." (énfasis agregado). Posteriormente, se reitera el juramento ex officio y, por si existían dudas de la inspiración inquisitiva, se establece el labrado de un acta casi siguiendo al pie de la letra a Aymerich y Peña. Los requerimientos importan cierta coerción psicológica y moral -así lo pensaban los inquisidores, v. gr., la silla que debía ocupar el indagado era más rústica que la del inquisidorcomo juego de las relaciones de poder. Por esta razón, en el Common Law el acusado no está obligado siquiera a sentarse a declarar, problemática advertida por el profesor Tedesco, quien 
sostiene que esta violencia ejercida atenta contra la presunción de inocencia a su vez que proscribe la posibilidad de hablar de la igualdad de posiciones propia del contradictorio, donde uno ya no puede ocupar uno de los vértices de todo conflicto, sino el centro de la escena.

El artículo $5^{\circ}$, reemplaza al $71^{\circ}$, reiterando la obligatoriedad del juramento ex officio cuando el acusado opte por tomar la palabra. El artículo $6^{\circ}$, modifica el $72^{\circ}$, donde se establece que el acusado no puede ser sometido por ninguna fuerza o coacción para declarar.

Respecto del Código Levene, el proyecto de ley trata el tema entre los artículos $7^{\circ}$ y $9^{\circ}$. El artículo $7^{\circ}$, modifica el $73^{\circ}$, estableciéndose la obligatoriedad del juramento condicionada al uso de la palabra. El artículo $8^{\circ}$ sustituye el conocido $296^{\circ}$ limitándose a agregar la instauración del juramento ex officio. Idénticamente, el artículo $9^{\circ}$, modifica el artículo $298^{\circ}$.

Claramente, el proyecto de "Ley de la Mentira" se distancia del ideario concebido en el Commonwealth, pero tampoco constituye a secas el juramento ex officio, pues, la ausencia de un elemento del binomio [juramento-tortura] es cuanto menos sugestiva. Amén de ello, merece la pena recordar que en nuestros antecedentes patrios la Asamblea del año XIII, primero proscribe la jurisdicción de la Inquisición limeña, luego los tormentos (y la destrucción de los elementos desatinados a ello) hasta que finalmente, hace lo propio con el juramento. En otras palabras, la privación del elemento tortura no le quita el carácter inquisitivo, máxime cuando en el texto de Aymerich - Peña puede advertirse sin hesitación que el acusado siempre prestaba juramento, aunque la tortura -como método para arrancar la confesión- quedaba relegada para determinados casos y circunstancias. En definitiva, el juramento continúa siendo el jusjurandum de veritate dicenda, aunque contiene matices distintivos.

Ante un escenario de por sí complejo, donde las mixturas están reñidas a muerte entre sí, el presente juramento sólo 
puede distorsionar más el sistema. Resulta difícil intentar seguir la senda del jury trial sin siquiera concebir la declaración performativa -con el consecuente juramento ordálico- como para a su vez sumarle el juramento ex officio. Parece inevitable pensar que mientras se añoran las costumbres inglesas se continúa sentado en la silla de Torquemada.

\section{Conclusiones}

En las páginas precedentes intenté hacer una aproximación sobre las funciones de los juramentos en las liturgias procesales. Una tarea ardua, pero satisfactoria. Así, siendo sintético me quedaré con las siguientes ideas: el juramento ex officio durante algún tiempo fue una característica común entre los paradigmas del procès y del trial. Cada paradigma evoluciona en formas disímiles, de esta inconmensurabilidad surgen las respuestas diversas que se dieron sobre asuntos idénticos.

Mientras que el trial, que conserva importantes características de las ordalías carolingias, brinda mayor proyección a la garantía de nemo tenetur -y siendo una solución conteste con el juramento ordálico-, la enquête se limita a la proscripción del juramento, pero brindando menor intensidad en la fuerza normativa tuitiva. En definitiva, son problemas de estructuras ideológicamente condicionadas que, en nuestro caso, impiden hablar de adversarialidad cuando no existe igualdad real -no formal- entre los oponentes, por más beneficiosa que sea la oralidad -cuando no es actuada- no logra sitiar los vestigios inquisitivos imperantes.

El acento de este trabajo está puesto en la funcionalidad de los juramentos ex officio y el ordálico. Creo que el contraste entre ambos resulta más interesante. Así, mientras que el primero, tiene un sentido probatorio [confesión] y por eso se relaciona con la tortura [binomio: juramento-tortura], el segundo actúa como aceptación de la puesta a prueba judicial tras la declaración performativa traducida en no culpabilidad. Posteriormente, el acusado puede testificar en su propia causa. Entre ambas 
declaraciones existe una lógica que es, en definitiva, acceder al juicio y probar la tesis inicial propuesta.

\section{Bibliografía}

\section{a. Libros}

AYMERICH, Nicolás; y, PEÑA, Francisco, El manual de los inquisidores, Ed. Muchnik editores, España, 1983.

BREGANTIC, Jonatan L., Iura novit curia, poder y verdad, Ed. Ad Hoc, Buenos Aires, 2019.

DE LA TORRE, José I., Breve historia de la Inquisición, Ed. Nowtilus, Madrid, 2014.

FOUCAULT, Michel, Obrar mal, decir la verdad. La función de la confesión en la justicia, Ed. Siglo Veintiuno, Buenos Aires, 2014.

GARIBALDI, Gustavo E. L., Sistemas de juzgamiento de delitos en la Argentina, Ed. Ad Hoc, 2015.

HARFUCH, Andrés, El juicio por jurados en la provincia de Buenos Aires, Ed. Ad Hoc, Buenos Aires, 2013.

HENDLER, Edmundo -Director-, Sistemas procesales comparados, Ed. Ad Hoc, Buenos Aires, 2015.

HENDLER, Edmundo, Derecho Penal y Procesal Penal de los Estados Unidos, Ed. Ad Hoc, Buenos Aires, 2006.

JACOB, Robert, La gracia de los jueces. La institución judicial y lo sagrado en Occidente, Ed. Tirant lo Blanch, Valencia, 2017.

MORENO, Juan Damián, La decisión de acusar. Un estudio a la luz del sistema acusatorio inglés, Ed. Dykinson, Madrid, 2014.

PORTERIE, Sidonie y ROMANO, Aldana, El poder del jurado: Descubriendo el juicio por jurados en la provincia de Buenos Aires, Ediciones del INECIP, Ciudad Autónoma de Buenos Aires, 2018.

RIGHI, Esteban -Director-, Cuadernos de Doctrina y jurisprudencia Penal No 6, Ed. Ad Hoc, Buenos Aires, 1997.

SANTA PINTER, José Julio, Sistema del Derecho Anglosajón, Ed. Depalma, Buenos Aires, 1956.

SUCAR, Germán y CERDIO HERRÁN, Jorge A. (eds.), Derecho y Verdad II. Genealogía(s), Ed. Tirant lo Blanch, Valencia, 2015. 
TEDESCO, Ignacio, El acusado en el ritual judicial, Ed. Didot, Buenos Aires, 2014.

THOMAS, Cheryl, Exposing the myths of jury service en Criminal Law Review, Vol.: 415, Issue: 6, Sweet \& Maxwell, Editor Ian Dennis, Inglaterra, 2008.

\section{b. Páginas web}

http://ravignanidigital.com.ar/asambleas/asa1/asa1110064.jpg https://revistas.unal.edu.co/index.php/hisysoc/article/view/ 32322/32341

https://www.britannica.com/topic/peine-forte-et-dure https://www.diariojudicial.com/public/documentos/000/086/

593/000086593.pdf?fbclid=IwAR1vrMTYxA-8vxJOvrm5zIxc1zm-V7eX-Sc8Q9-DRfiK5ALfuI-o55fzczI

https://www.justice.gov.uk/courts/procedure-rules/criminal/docs/

2015/criminal-procedure-rules-practice-directions-april-2019. pdf

https://www.loc.gov/law/help/statutes-at-large/45th-congress/ session-2/c45s2ch37.pdf

https://www.uscourts.gov/statistics-reports/us-district-courtsjudicial-business-2018

\section{c. Jurisprudencia}

CSJN, "Criminal, contra Eduardo Mendoza, por falsificación de un manifiesto de Aduana" (Fallo, 1:350), 28/10/1864.

CSJN, "Oscar Rodríguez Pamia y Otro" (Fallo, 227:63), 19/10/1953.

CSJN, "El Atlántico" (Fallo, 281:177), 22/11/1971.

SCJ EEUU, "Brown v. Walker" (161 US., 591, 1896). 